Ars Disputandi

Volume 4 (2004)

ISSN: $1566-5399$

Henk-Jan Prosman

UTRECHT UNIVERSITY, THE

NETHERLANDS

\title{
The Cambridge Companion to Postmodern Theology
}

\author{
Edited by Kevin J. Vanhoozer
}

Cambridge: Cambridge University Press, 2003; 295 pp.; hb. £ 42.50, pb. $£$ 15.99; ISBN: 0-521-79062-x/o-521-79395-5.

[1] The Cambridge Companion to Postmodern Theology consists of two parts. The first part offers an overview of no less than seven currents in postmodern theology. ('Anglo-American Postmodernity' by Nancey Murphey and Brad J. Kallenberg; 'Postliberal Theology' by George Hunsinger; 'Postmetaphysical theology' by Thomas Carlson; 'Deconstructive theology' by Graham Ward; 'Reconstructive theology' by David Ray Griffin; 'Feminist theology' by Mary McClintock Fulkerson and 'Radical Orthodoxy' by Stephen Long) The second part of the book takes off from Christian dogmatics and gives an impression of what a postmodern methodology could mean in developing dogmatic loci. In this part David Cunningham writes on the Trinity, 'God and world' is discussed by Philip Clayton, 'the human person' by John Webster. 'Christ and salvation' by Walter Lowe and 'Ecclesiology' by Stanley Grenz. An essay on 'Holy Spirit and Christian Spirituality' is written by David Ford. More general essays are offered by editor Vanhoozer. He introduces the first part with 'Theology and the condition of Postmodernity: A Report on Knowledge (of God)', and the second part with an essay titled 'Scripture and Tradition'.

[2] In this review, I will discuss four essays from the book. I start with Vanhoozers introductory essay "Theology and the condition of postmodernity; a report on knowledge (of God)' (1). The second essay I discuss is a contribution of Nancey Murphy and Brad Kallenberg on Anglo-American postmodernity (2). From the second part of the book I will discuss Stanley Grenz's essay on Ecclesiology (3). Finally I discuss Long's essay on Radical Orthodoxy (4). I will conclude with some evaluative remarks on the essays discussed and the book as a whole (5).

1

[3] Vanhoozer raises the important question what it would mean for theology if there would be something like a postmodern condition. Vanhoozer sees the postmodern not so much as a new condition for theology, but as a theological condition. This of course makes the reader curious as to what makes postmodernity so inherently theological. Vanhoozer sees the central claims of modern Enlightenment rationality as 1) that reason is absolute and universal, 2) that individuals 
are autonomous, able to transcend their time and place, 3) that universal principles and procedures are objective whereas preferences are subjective. (p.8) Postmodernity is the démasqué of this universal aspiration. 'It is a move away from the authority of universal science, toward narratives of local knowledge.' (p.10) Postmoderns reject 'unifying, totalizing, and universal schemes in favor of new emphasis on difference, plurality, fragmentation and complexity.' (p.11) Ultimately the postmodern condition is linguistic and textual; Humans are 'sentenced to interpretation'. In reply to the universal and total aspirations of modernism, postmodernism is a movement of recovery. More specific, the postmodern condition has enabled 'the recovery of two neglected forms of religious discourse the prophetic and the mystical - that seek, in different ways, to invoke the beyond: justice, the gift' (p.17) Postmodernism has made possible the return of the repressed, through its appreciation of particularity and difference. It is especially this messianic reading of the religious that Vanhoozer seems to appreciate: 'On this view the postmodern conception is essentially, that is structurally, messianic: constitutionally open to the coming of the other and the different. Faith, not reason - faith in a religionless (viz., messianic) religion - is thus endemic to the postmodern condition.' (p.18) Thus Vanhoozer defines postmodernism as ultimately a theological condition, for it situates 'modernity and postmodernity alike within the story of what relates both what God is doing in the world through Jesus Christ and the Holy Spirit and what the world is doing in response.' (p.21) God thus transcends the meta-narratives that Lyotard was criticizing. The critique towards the modern meta-narratives doesn't touch upon the ultimate meta-narrative that situates the human within the narrative of Gods creative and redemptive activity.

\section{2}

[4] In the second essay, on Anglo American postmodernity, Murphey and Kallenberg sketch in a clear way the tradition of representationalism from Descartes to Kant and the liberal theology of the $19^{\text {th }}$ century. What has been called 'Cartesian anxiety' gave rise to a quest for foundations in every academic discipline and made the prolegomena a necessary starting point for theology. Wittgenstein is presented as the philosopher who has shown 'the fly the way out of the bottle of Cartesian anxiety'. He showed the senselessness of the Cartesian enterprise to separate subjects and objects and showed that 'clarity begins with an acknowledgement of the irreducibly social character of human experience and the intrinsic relation of human experience to the real world.' (p.35) John Howard Yoder and Nicholas Lash are introduced as theological inheritors of Wittgenstein. In the light of what Wittgenstein said on language and forms of life, the task of the theologian becomes 'to coach believers in the proper use of first order language in a way that enables them to see the pattern of God's presence in the realm of the ordinary.' (p.36) With Yoder the theologian should focus on concretely existing communities, rather than on theoretical foundations. Moral and religious communities exist; we cannot validate them, all we can account for is a posteriori elucidation. This amounts to a reading of postmodernism as an omega shaped 
detour (a metaphor of Toulmin). In the end postmodernism turns back to a premodern, pre-critical understanding of theology. According to Murphey and Kallenberg, postmodern critique makes it possible to shrug off all epistemological problems and engage in the tradition the theologian finds oneself in.

\section{3}

[5] In the essays discussed so far, the central issue in postmodern critique is the crucial importance of community, tradition and language to our idea of rationality. That is why I now want to turn to Grenz's essay on ecclesiology. Grenz's conviction is that the contemporary appreciation of communal life is at the heart of theology and ecclesiology. Community with others and community with God are fundamental to understanding human agency and understanding the Christian tradition. Communities provide a 'transcendent vantage point for life in the here-and-now. It bestows a qualitative meaning upon time and space, and upon community members as they inhabit their world.' (p.256) Central problem for Grenz is to distinguish the Christian community from the secular realm in a significant way and to avoid sociology to become the new foundational discipline. The postmodern emphasis on community makes the question important as to what kind of a community the church is, in what way it is distinct, and how it is not derivative from a general, sociological understanding of community. For this purpose Grenz takes recourse to the apostolic creed. He develops the adjectives one, holy, catholic, and Christian in a protestant and missionary way. The Christian community is found where the gospel is preached and the sacraments are celebrated. This makes the Christian community both particular and universal. In the narrative of the sacraments, believers participate in the great divine narrative. Essential is an eschatological understanding of the church. Not everything we believe of the community is realized here-and-now. This marks the church as missionary. In the end the community of the church - as a community 'in Christ' - is a perichoretic community having its life in the triune God.

\section{4}

[6] The essay on Radical Orthodoxy is more critical towards postmodernism. The author defines the postmodern epistemology as a metaphysics of violence. In its resistance against modern philosophy, the metaphysics of difference is itself totalitarian. Unlike many atheistic critics have argued, Christianity is not dependant on a metaphysics of presence. Drawing on Hans Urs von Balthasar, Long claims that orthodox Christology does not claim an image of God standing over against what is imaged, but sees Christ as a unique hypostatic union between archetype and image. Interpreting Christology as a hypostatic union, Christian theology not only overcomes a metaphysics of presence, it also avoids the nihilistic postmodern strategy to overcome presence through its constant deferral. As Long states it: 'It heals us from thinking we must acquiesce to ontological violence.'(p.133) Because Jesus is not merely a mirroring of the absent father, Christian theology cannot be deconstructed by the postmodern critique of différance. Radical Orthodoxy is 
capable of overcoming metaphysics, criticizing both modernity and postmodernity for having preferred a void over matter: 'Theology can turn the violence of metaphysics and the secular back to what has been forgotten - theology or, more importantly, God.' (p.134) In the first place, this turn is a questioning of the dualism between faith and reason, philosophy and theology. Subsequently, Long discusses this 'turn' in rereading five philosophical themes: (a) the linguistic nature of reason, (b) the ontological difference, (c) the priority of existence over essence, (d) the priority of dialogue, and (e) the sensuality of all human thought.

[7] Especially (a) is interesting, for radical orthodoxy can help us escape the postmodern obsession with language. Linguistic frameworks can easily become new transcendental presuppositions. In Radical Orthodoxy 'the linguisticallity of reason cannot put a priori constraints on human language, since it 'participates via analogy in God's eternal plenitude.' (p.136) This sounds to me like an original contribution to the contemporary debate. Instead of sliding back in mere historicism and relativism, Radical Orthodoxy makes us sensitive to the fact that Christian faith presupposes a metaphysics of its own that is not a mere complement to modernity, nor its postmodern denial. My impression is that Radical Orthodoxy, as presented here by Long, offers quite some new perspectives for Christian thought. However, pretty much hangs on the credibility of the 'hypostatic Christian ontology'. This might sound credible to those already in the Christian tradition, but instead of bridging the gap between theology and philosophy, it might easily widen it. Classical Christianity is presented as providing a genuine alternative to a convincingly demonstrated aporia in modern and postmodern thinking. (See for example the discussion of alterity in Derrida and Levinas at pages $140-142$ )

\section{5}

[8] The main contribution of the Cambridge Companion to Postmodern Theology is that it shows that postmodernism is 'everybody's business'. 'To be postmodern,' Vanhoozer writes in the Preface, 'is to signal one's dissatisfaction with at least some aspect of modernity.' As long as modernism offers at least some dissatisfaction, postmodernism should be seen as an indispensable conversation partner. This book contributes to that conversation in a laudable way. Moreover, the essays are written at a level that makes them both challenging to the expert and accessible to students and non-experts in the field.

[9] At the same time, I must say, the optimistic tone in which some parts of the book are written is striking. Vanhoozer is eager to criticize dogmatic theology in favor of narrative theology. But we may ask, can the narrative stand on itself? Can we take for granted the 'canonical Scriptures and the Catholic tradition', or are the latter credible only against the background of stronger epistemological claims viz. the metaphysical tradition? And could not the postmodern critique that Vanhoozer so warmly welcomes, just as easily deconstruct the great words of the tradition Vanhoozer so ardently invokes. Reading Grenz's essay for example, I get the impression that it is written against the background of a tacit agreement 
on a lot of topics, including some quite universal ideas such as 'the destiny God intends for creation'. (p.260) This at least sounds a bit odd in a volume criticizing Enlightenment's universal aspirations.

[10] To my mind postmodernism is most challenging and stimulating for theology. This should not make us lose sight, however, of some of its problematic aspects. In emphasizing community and forms of life postmodern theology runs new risks, such as tribalization, pluralism and trivialization. In this respect, Radical Orthodoxy remains an interesting case, because it is sympathetic to postmodernism, while at the same time criticizing and in a way rejecting it. 